Journal of Economics and Behavioral Studies

Vol. 3, No. 5, pp. 279-286, Nov 2011 (ISSN: 2220-6140)

\title{
Moderating Role of Social Exchange Perceptions between Perceived Organizational Politics and Antisocial Behavior
}

\author{
Mahmood A. Bodla ${ }^{1}$, ${ }^{*}$ izwan Qaiser Danish ${ }^{2}$ \\ ${ }^{1}$ COMSATS Institute of Information Technology, Lahore, Pakistan \\ ${ }^{2}$ COMSATS Institute of Information Technology, Islamabad, Pakistan \\ *rdanish2000@yahoo.co.uk
}

\begin{abstract}
Organizational politics is a fact of organizational life, which can be seen in almost every type of organization globally. Individuals come together for a common purpose and safeguard self interest. The present study examines the moderating role of social exchange perceptions between perceived organizational politics and antisocial behavior in Pakistani context. The empirical evidence is based on the national level sample data as collected through self-administered questionnaires from executives of multitude of Pakistani industries such as health, manufacturing, energy, financial services, education, telecommunication, and information technology. The sample comprised of 577 respondents. Moderated hierarchical regression was applied to test the interactional effects and hypothesized relationships were confirmed. Several practical implications have been provided for the benefit of practicing managers.
\end{abstract}

\section{Keywords: Organizational politics, social exchange, perceptions, antisocial behavior}

\section{Introduction}

Social Exchange Theory explains that employees in organizations always think their relationships with others in economic terms and gains. They match the cost of this relationship with perceived rewards (West \& Turner, 2000). Many researches in psychology confirmed that interpersonal behaviors are based on and revolve around resource seeking (Foa \& Foa, 1974). However, allocation of resources and budget is subject to favoritism and power relations which ultimately produce an environment of politics in an organization. West and Turner (2000) asserted that individuals see life like a marketplace where costs and rewards are involved. Where there is manipulation of resources and their unequal distribution, the behaviors of employees may not conform to the social norms of a particular organization thus leaving room for some deviant workplace actions.

The present study is an attempt to find some mechanisms under which social exchange perceptions operate, specifically its interactional effects are taken into consideration while relating perceptions of organizational politics to antisocial behaviors. The purpose is to find some implications by which managers can improve the working relations and behaviors at work. This would be the first study of its nature in Pakistani context, which will address this sensitive issue.

\section{Literature Review}

Organizational Politics: Politics is a fact and is widespread in organizational life. It permeates each group of individuals who come together for a common purpose. Although 'politics' usually has a negative connotation, it is not necessarily that. Organizational politics is "a social influence process in which behavior is strategically designed to maximize short-term or long-term self-interest, which is either consistent with or at the expense of others' interests" (Ferris et al., 1989). Others see organizational politics as "the management of influence to obtain ends not sanctioned by the organization or to obtain sanctioned ends through nonsanctioned influence means" (Mayes \& Allen, 1977).

Ferris et al. (1989) developed a model of perceptions of organizational politics, which brought life in the area of organizational studies. Various investigations were carried out to validate and confirm this model. Revised 
versions of this model were also prepared later on. The important development in this model is that it encompasses the factors that influence the perceptions of organizational politics by the employees and its impact on organizational performance. Perceptions of Organizational Politics (POP), as explained by Chivakidakarn et al. (2009) and is organized around three factors: (1) general political behavior; (2) 'go along to get ahead'; and (3) pay and promotion policies. General political behavior, the first factor, describes the employees behavior which is revealed through their self-serving acts in a manner to obtain outcomes they think are valuable. 'Go along to get ahead' describes behaviors such as being silent and taking no action in order to make safe valued outcomes. Pay and promotion policies involve the organizations' political behavior in which the policies are manipulated and favors are given to those who are not on merit. Political behavior will spread widely in the organizations when there are deficiencies in rules and regulations to govern certain actions (Chivakidakarn et al., 2009).

Social Exchange: Social exchange refers to as long-term efforts in which each party is supported in contributing its role, which is symbolic, immaterial and based on personal value (Haas \& Deseran, 1981). People working in an organization are involved in some type of social relations in one way or the other mutually (Blau, 1964) which may be sentimental exchange, social exchange and economical exchange (Emerson, 1976). These relationships provide instructions as well as extrinsic value for employees in future endeavors. The employees having high quality social exchanges also possess higher level of commitment for their organizations (Masterson et al., 2000) and their turnover rate is usually very low (Tekleab et al., 2005). Social exchange is generally considered as social interaction between employees and organization and one of the outcomes of this interaction is long-term relationship between employees and the organization (Cropanzano \& Mitchell, 2005). Social exchange as major effects on job performance that has been confirmed by various studies (Tsui et al., 1997; Dirks \& Ferrin, 2002; Rhoades \& Eisenberger, 2002). This social relationship is present in all work setting and every working relationship in one way or the other (Shore and Barksdale, 1998). Many researches (Blau, 1964; Molm et al., 2000; Haas \& Deseran, 1981) have found various objectives of social exchanges in many disciplines like sociology, social psychology and anthropology.

Shore et al. (2006) have pointed that in social exchange emphasis is on emotional relation, long-term relationship, high investment on employees and high level of organizational trust is involved. The more attention towards the needs of employees makes these social exchanges with organization more valuable (Kramer, 1991). In this way better performance and more commitment is seen and economic rewards are not expected or paid attention to (Tsui et al., 1997). Social exchange relations enhance the employee's dependence on their organizations. Nevertheless, when these exchanges are perceived as unfair, the employees tend towards the financial benefits or economic rewards. They compare their salary, rewards and promotion policies with other organizations and their loyalty decreases which ultimately results in their quital from the organization. Social exchange in organization appears when one employee attracts to other while expecting the economic reward of this relationship (Blau's, 1964).

Antisocial Behavior: According to Frick (1998), antisocial behavior is defined as such behaviors, which are the results of violation of others, right, deviation from the social norms, or not meeting the expectations of authorities. These behaviors are developed within a long period of time and slowly. The list of such behaviors has been given in Table 1. According to Robinson and Bennett, (1995) "voluntary behavior that violates significant organizational norms and in so doing threatens the well-being of an organization, its members, or both". These behaviors have damaging affects and sometime individuals intentionally do not follow the directions of superiors. Antisocial behavior, sometime also known as counterproductive work behaviors cause to decrease imbalances in the relationship of social exchange. Such behaviors produce negative emotions, which results in non-productive behavior (Storm \& Spector, 1987). Although psychological tests and background checks maybe helpful in determining deviations proactively (Robinson \& O'Leary-Kelly, 1998) but even then the organizations have to pay cost for the future behaviors. Such behaviors are discouraged as they involve much cost by creating and implementing rules (Sackett \& DeVore, 2002) but effective enforcement of such rules is very rare in evidence. The question of such behavior being ethical or not is a difficult question. Robinson and Bennett (1995) presented typology of workplace deviance which describes two dimensions of behaviors; minor versus serious and interpersonal versus organizational. 
There are various work behaviors in organization, which are counter productive and are result of imbalances produced by social exchange relationships (Storm \& Spector, 1987). Different researchers have named these set of behaviors differently. Some of the labels used for such behaviors are organizational deviance, dysfunctional behavior, antisocial organizational behavior, counterproductive behavior and organizational misbehavior (Robinson \& Bennett, 1995). We will term these behaviors as antisocial behavior in our study as suggested by (Giacalone \& Greenberg, 1997). A behavior is considered to be deviant when an "organization's customs, policies, or internal regulations are violated by an individual or a group that may jeopardize the well-being of the organization or its citizens" (Robinson \& Bennett, 1995). In the following table (Table 1) we have mentioned different types of behaviors used by different researchers.

Table 1: Different Categories of Antisocial Behaviors

\begin{tabular}{|c|c|}
\hline Researchers on Workplace Deviance & Potential Deviance/Antisocial Behaviours \\
\hline Fox, Spector, \& Miles, 2001 & Aggression, interpersonal conflict, and theft \\
\hline Robinson and O'Leary-Kelley, 1998 & $\begin{array}{l}\text { Breaking rules, damaging company property, hurting other } \\
\text { workers, starting arguments with co-workers, and saying rude } \\
\text { things about a supervisor or the organization }\end{array}$ \\
\hline Frick, 1998 & $\begin{array}{l}\text { Assault, vandalism, setting fires, theft, prolonged runaway, crime, } \\
\text { opposition, defiance, arguing. }\end{array}$ \\
\hline Giacalone and Greenberg, 1997 & $\begin{array}{l}\text { Stealing, sexually harassing, use alcohol or drugs on the job, } \\
\text { sabotage production, behave violently, gossiping }\end{array}$ \\
\hline Everton et al., 2005 & Online banking, Personal e-mail, downloading pornography \\
\hline Galperin, 2002 & $\begin{array}{l}\text { Not following the manager's instructions, committing petty theft, } \\
\text { acting rudely with co-workers, intentionally slowing down the } \\
\text { work cycle, arriving late, not treating co-workers, }\end{array}$ \\
\hline
\end{tabular}

Robinson and Bennett, 1995

Sabotage or absenteeism, theft, computer fraud, embezzlement, vandalism, property deviance, political deviance, production deviance and personal aggression

Henle et al., 2005 Physical aggression, belittling others, playing pranks on others, arguing, and acting rudely

Hypotheses: For this study, we have developed the following hypotheses;

H1: Perceptions of Organisational Politics are negatively strongly and correlated with Social Exchange Perceptions

H2: Perceptions of Organisational Politics are strongly and positively correlated with Anti Social Behavior

H3: Social Exchange Perceptions are strongly and negatively correlated with Anti Social Behavior

H4: Social Exchange Perceptions have strong moderating effect between Perceptions of Organisational Politics and Anti Social Behavior

\section{Methodology}

Purposive sampling technique was used to collect the data from such employees who are well aware of the policies of organization and free to respond away from their respective organizations. Part time executive class students were chosen for the purpose that were enrolled in MBA evening and attend classes after fulfilling their routine duties. The empirical evidence is based on the national level sample data as collected through self-administered questionnaires from executives of multitude of Pakistani industries such as health, manufacturing, energy, financial services, education, telecommunication, and information technology. The sample comprised of 577 respondents. Overall 600 questionnaires were distributed among which 589 were returned, three were discarded due to multiple responses on the same items, 9 were rejected due to incomplete data reporting, thus comprising of $96 \%$ useable responses. The participation in this survey was voluntary ensuring confidentiality and anonymity of the participants. 
Measurements of Variables: Perception of organizational politics is the "degree to which respondents view their work environment as political and therefore unjust and unfair" (Ferris et al., 1989). A nine items revised version of POPS was used which was developed by Kacmar and Carlson (1997) and has three subscales. Five anchored Likert type scale was used in ranging from one (Strongly Disagree) to five (Strongly Agree). Social Exchange Perceptions: Employees' perceptions of their organizational exchange relationship was measured using Shore et al. (2006) eight item scale which asses the employees' perceptions of the social exchange relationships that they have with their organization. All the items were measured on 5-point Likert scale ranging from 1 (Strongly Disagree) to 5 (Strongly Agree).

Antisocial Behaviour: According to Robinson and O'Leary-Kelley (1998), antisocial behavior describes negative behaviors by employees that have the potential to harm individuals and/or organization. Antisocial behaviours include breaking rules, damaging company property, hurting other workers, starting arguments with co-wokers, and saying rude things about a supervisor or the organization. It was measured through Antisocial Behaviour Scale developed by Robinson \& O'Leary-Kelly (1998). All the items were measured on 5 point Likert scale ranging from 1 (Strongly Disagree) to 5 (Strongly Agree).

\section{Results}

The collected data through survey questionnaire was entered into SPSS and hypotheses were tested using appropriate analysis. First, Descriptive statistics were found and results are presented as follows;

Among 577 respondents, males were dominant (about 90\%), $62 \%$ were married and 28\% within age group 30-39. 32\% employees were from public sector. Most of the respondents were from financial services (36\%). $24 \%$ employees were from large establishments where more than 500 employees were the part of that organization. Mean and Standard Deviation were found which show that all the three variables have mean values above average, specifically social exchange perceptions have the highest mean $(M=3.52)$. On the other hand standard deviation for Antisocial Behavior is highest $(S D=.74)$. The results are given in Table 2 .

Table 2: Mean and Standard Deviation of Variables ( $N=577)$

\begin{tabular}{lll}
\hline Variables & Mean & Std. Deviation \\
\hline Perceptions of Organisational Politics & 3.00 & .50 \\
Social Exchange Perceptions & 3.52 & .58 \\
Anti Social Behavior & 3.00 & .74 \\
\hline
\end{tabular}

Table 3 presents the results of Pearson correlation among the three variables. There is strong and negative correlation $(r=-.223)$ between Perceptions of Organisational Politics and Social Exchange Perceptions which confirms our first hypothesis, H1. The second hypothesis states that Perceptions of Organisational Politics are strongly and positively correlated with Anti Social Behavior and r-value .378 shows strong positive relationship, however, there is not significant relationship between Social Exchange Perceptions and Antisocial Behavior.

Table 3: Correlations among variables $(N=577)$

\begin{tabular}{|c|c|c|c|c|}
\hline \multirow[t]{2}{*}{ Variables } & \multirow{2}{*}{$\begin{array}{l}\text { Perceptions } \\
\text { Organisational Politics }\end{array}$} & of Social & \multirow{2}{*}{$\begin{array}{l}\text { Exchange Anti } \\
\text { s } \quad \text { Behaviour }\end{array}$} & \multirow[t]{2}{*}{ Social } \\
\hline & & Perceptions & & \\
\hline \multirow{2}{*}{$\begin{array}{l}\text { Perceptions of } \\
\text { Politics }\end{array}$} & 1.000 & $-.223^{* *}$ & $.378^{* *}$ & \\
\hline & & .000 & .000 & \\
\hline \multirow[t]{2}{*}{ Social Exchange Perceptions } & $-.223^{* *}$ & 1.000 & -.011 & \\
\hline & .000 & & .784 & \\
\hline \multirow[t]{2}{*}{ Anti Social Behaviour } & $.378^{* *}$ & -.011 & 1.000 & \\
\hline & .000 & .784 & & \\
\hline
\end{tabular}


Moderation Tests: Moderating role of a variable can be identified by introducing such variable between independent and dependent variable generally done by linear regression. A moderator variable is one which changes the strength or form of the relationship between independent and dependent variables. We run regression analysis to test the model that antisocial behavior is a linear function of perceived organizational politics, but we hypothesized that the slope for the regression of antisocial behavior on perceived organizational politics changes across levels of a moderator variable, social exchange perceptions. To make it more precise, we think that there is an interaction between antisocial behavior and social exchange perceptions with respect to their effects on perceived organizational politics. We used ITALASSI software to display the interactional effects in form of a plot. As the relationship between perceived organizational politics and antisocial behavior changes with change in social exchange perceptions from low to high value, it can be represented in figures below. We can also find any point between low and high values by rotating the graph.

Figure 1 shows that in the presence of lower level of social exchange perceptions there is negative relationship between the Perceptions of Organizational Politics and Antisocial Behavior and both values tends to higher level. On the other hand, Figure 2 presents the reverse case. When social exchange perceptions are at higher level this relationship becomes positive which indicates that higher perceptions of organizational politics lead to higher level of antisocial behavior. So the introduction of social exchange perceptions intensifies the linear relationship thus showing the strong moderating or interactional effects. In this way our final hypothesis $\mathrm{H} 4$ is confirmed.

Figure 1: Relationship between Perceptions of Organizational Politics and Antisocial Behavior when Social Exchange Perceptions are at low level

Relationship between Perceptions of Organisational Politics and Anti Social Behaviour When Social Exchange Perceptions is equal to 1.62

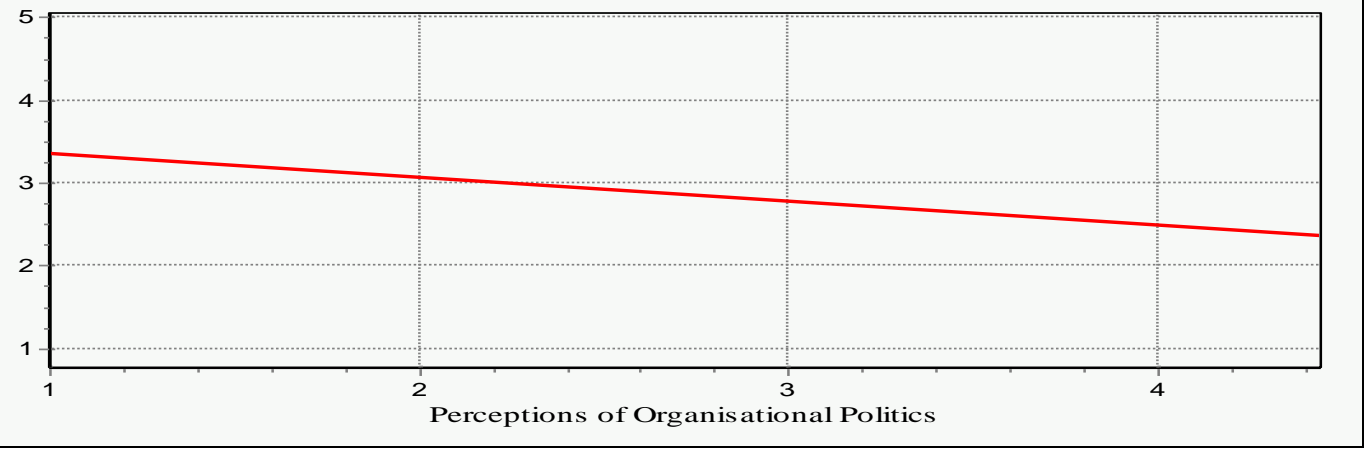

Figure 2: Relationship between Perceptions of Organizational Politics and Antisocial Behavior when Social Exchange Perceptions are at High level

Relationship between Perceptions of Organisational Politics and Anti Social Behaviour When Social Exchange Perceptions is equal to 5

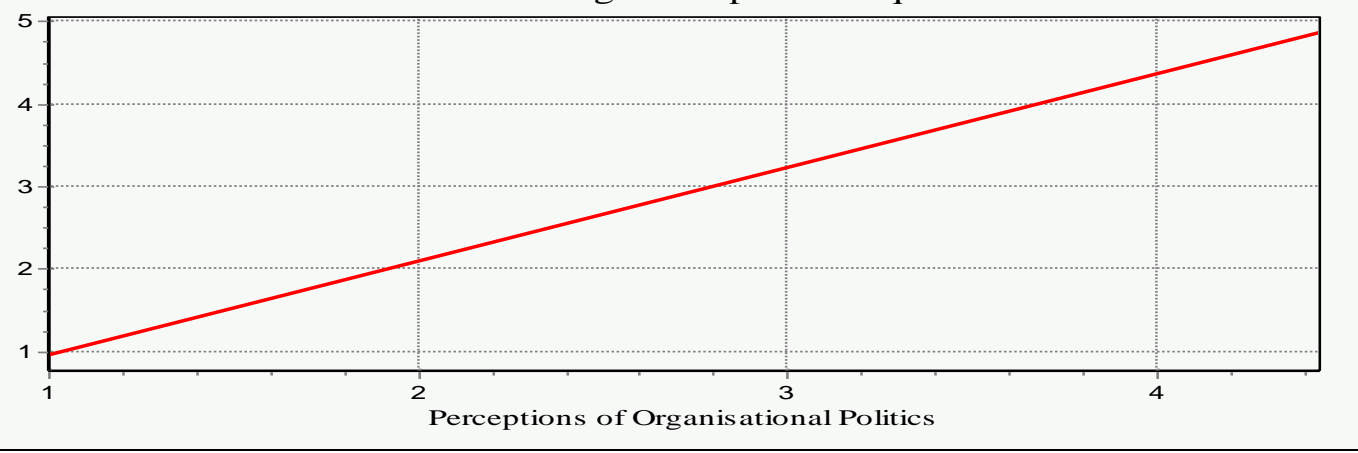


The moderating effects have also been measured by using Baron and Kenney (1986) criteria for moderating variables. Moderating variable is not correlated with dependent variable in any significant way. Moreover, moderating variable and Independent variable are at the same level to affect the dependent variable. We can see from Table 4 different indices of goodness of fit of a model.

Table 4: Regression Results with Interactional Effects ( $N=577)$

\begin{tabular}{llllllllll}
\hline Model & & B & S.E. & Corr & S.Part & Partial & t & Prob & $\mathbf{R}^{2}$ \\
\hline \multirow{2}{*}{2} & B0 & 1.3326 & & & & & & & \\
& B1 & .5572 & .0568 & .378 & .378 & .378 & 9.81 & .000 & .143 \\
& B0 & 3.0554 & & & & & & & \\
& B2 & -.0145 & .0529 & -.011 & -.011 & -.011 & .27 & .784 & .000 \\
& B0 & .9143 & & & & & & & \\
& B1 & .5824 & .0582 & .378 & .386 & .386 & 10.02 & .000 & \\
& B2 & .0973 & .0501 & -.011 & .075 & .081 & 1.94 & .053 & .149 \\
& B0 & 5.4908 & & & & & & & \\
& B1 & -.9717 & .3360 & .378 & -.109 & -.120 & 2.89 & .004 & \\
& B2 & -1.1312 & .2664 & -.011 & -.161 & -.175 & 4.25 & .000 & \\
& B3 & .4202 & .0895 & .329 & .177 & .192 & 4.69 & .000 & .180 \\
\hline
\end{tabular}

Beta values are significant at the 0.001 or 0.01 level

Following are the different models obtained through regression analysis. Model 4 has the highest value of $\mathrm{R}$ square thus confirming our hypothesis regarding the interactional effects of social exchange perceptions between perceptions of organizational politics and antisocial behavior.

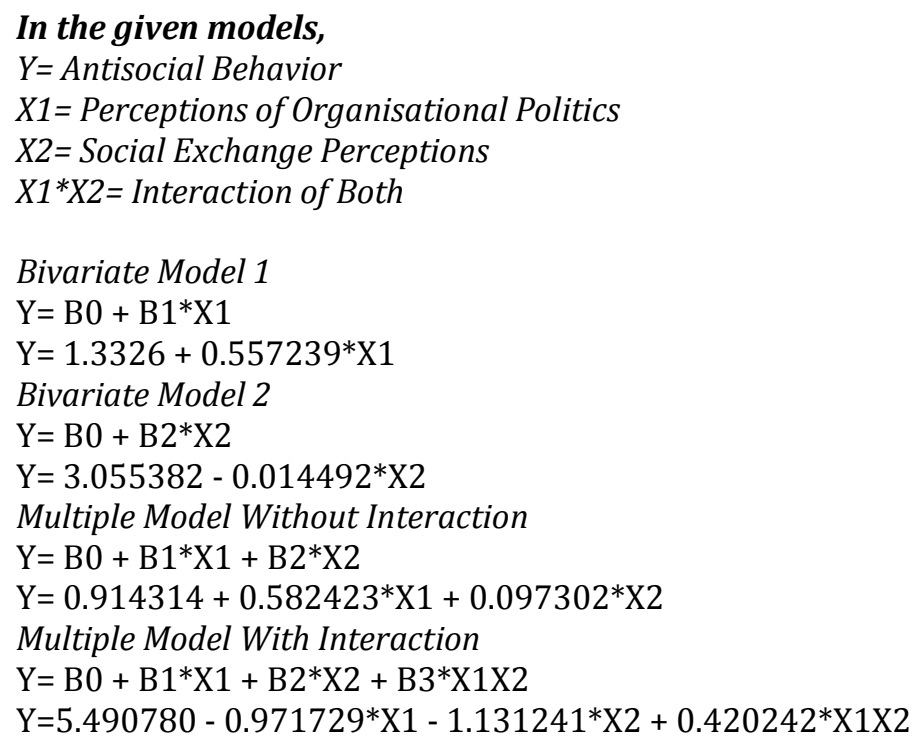

\section{Conclusion and Recommendations}

The primary purpose of this study was to investigate the moderating role of social exchange perceptions in relating perceptions of organizational politics to antisocial behavior. We developed four hypotheses and H1, H2, H4 were fully supported, and however, there was partial support for H3. H3 states that Social Exchange Perceptions are strongly and negatively correlated with Anti Social Behavior. Nevertheless, the results reveal that although this relationship is negative but not as stronger as was expected. Research has widely focused on the negative outcomes of the organizational politics that is why our hypothesized relationship was 
confirmed. Where there prevails the environment of favoritism and people attempt to build themselves up by tearing others down, the presence of bad, slow or incorrect work, breaking rules, criticism and argumentation are common behaviors of employees. Therefore, the people may immune to the environment. On the other hand the highest mean value of social exchange perceptions $(M=3.58)$ is telling some other story. Employees think that organization is investing on them, which will result in their career growth and help achieve their terminal values. However, these give and take relationship or relationship of mutual trust within organization is just to safeguard personal objectives rather than overall organizational objectives. They put their best efforts but expect something more than reward and recognition. They want to be the part of coalition and such network, which is not only in the good books of top management but also other members of organization. The role of social exchange is very important in such context. The employees must believe that there is a lot of give and take in their relationship with organization. They must focus on long-term standings with their organization. Sometime they do not put extra effort on behalf of their organization as they think they will not be rewarded properly.

No doubt, managers and the organizations where antisocial behaviors exist, they want to reduce them to a minimum level. Managers can handle these behaviors by making rules and implementing those while allowing the participation of employees in developing rules and policies. They can be handled by conducting seminars and lectures on organizational citizenship behaviors, communicating to them the moral values and ethical considerations and above all making the system clear and transparent in dealing with one an other. Strong and positive culture of ethics can be produced which can make employees feel confused while practicing any unethical activity or antisocial behavior. To enhance the understanding of such behaviors further, the researcher should see whether the construct of antisocial behavior be bundled or merged with that of organizational politics?

\section{References}

Baron, R. M. \& Kenny, D. A. (1986). Moderator-Mediator Variables Distinction in Social Psychological Research: Conceptual, Strategic, and Statistical Considerations. Journal of Personality and Social Psychology, 51(6), 1173-82.

Blau, P. M. (1964). Exchange and Power in Social Life. Wiley, New York. In:

Cropanzano, R., Howes, J.C., Grandey, A. A. \& Toth, P. (1997). The relationship of organizational politics and support to work behaviors, attitudes, and stress. Journal of Organizational Behavior, 18, 159-80.

Cropanzano, R. \& Mitchell, M. S. (2005). Social Exchange Theory: An Interdisciplinary Review. Journal of Management, 31(6), 874-900.

Chivakidakarn, Y., Dastoor, B. \& Mujtaba, B. G. (2009). Political Behavior of Thai Managers and Their Perceptions of Politicking. The IUP Journal of Organizational Behavior, 8(3 \& 4), 22-33.

Dirks, K. T. \& Ferrin, D. L. (2002). Trust in leadership: Meta-analytic findings and implications for research and practice. Journal of Applied Psychology, 87(4), 611-628.

Emerson, R. M. (1976). Social Exchange Theory. Annual Review of Sociology, 2, 335-362.

Everton, W. J., Jolton, J. A. \& Mastrangelo, P. M. (2005). Be nice and fair or else: understanding reasons for employees' deviant behaviors. Journal of Management Development, 26(2), 117-131.

Ferris, G. R., Russ, G. S. \& Fandt, P. M. (1989). Politics in organizations. In R.A. Giacalone and P. Rosenfeld (eds) Impression management in the organization. Hillsdale, NJ: Lawrence Erlbaum: 143-70.

Foa, U. G. \& Foa, E. B. (1974). Societal structures of the mind. Oxford, England: Charles C Thomas.

Fox, S., Spector, P. E. \& Miles, D. (2001). Counterproductive work behavior (CWB) in response to job stressors and organizational justice: Some mediator and moderator tests for autonomy and emotions. Journal of Vocational Behavior, 59, 291-309.

Frick, P. J. (1998). Conduct Disorders and Severe Antisocial Behavior. New York: Plenum Press.

Galperin, H. \& Bar, F. (2002). Open Access Beyond Cable: The Case of Interactive TV. Communication \& Strategies, 46(2), 75-98.

Giacalone, R. A., \& Greenberg, J. (1997). Antisocial behavior in organizations. Thousand Oaks, CA: Sage Publications, Inc.

Haas, D. F. \& Deseran, F. A. (1981). Trust and Symbolic Exchange. Social Psychology Quarterly, 44(1), 3-13. 
Henle, C. A. (2005). Predicting Workplace Deviance from the Interaction between Organizational Justice and Personality. Journal of Managerial Issues, 17(2), 247-263.

Kacmar, K. M. \& Carlson, D. S. (1997). Further validation of the perceptions of politics scale (POPS): A multiple sample investigation. Journal of Management, 23, 627-658.

Kramer, R. M. (1991). The more the merrier? Social psychological aspects of multi-party negotiations. In R. Lewicki, B. Sheppard, \& M. Bazerman (Eds.), Research on Negotiation in Organizations, 13, 307-332. Greenwich, CT: JAI Press.

Masterson, S. S., Lewis, K., Goldman, B. M., \& Taylor, M. S. (2000). Integrating justice and social exchange: The differing effects of fair procedures and treatment on work relationship. Academy of Management Journal, 43, 738-748.

Mayes, B. T. \& Allen, R. W. (1977). Toward a Definition of Organizational Politics. The Academy of Management Review, 2(4), 672-678.

Molm, L., Nobuyuki T. \& Gretchen, P. (2000). Risk and Trust in Social Exchange: An Experimental Test of a Classical Proposition. American Journal of Sociology, 105, 1396-427.

Rhoades, L. \& Eisenberger, R. (2002). Perceived organizational support: A review of the literature. Journal of Applied Psychology, 87, 698-714.

Robinson, S. L. \& Bennett, R. J. (1995). A typology of deviant workplace behaviors: a multidimensional scaling study. Academy of Management Journal, 38, 555-572.

Robinson, S. L. \& O'Leary-Kelly, A. M. (1998). Monkey see, monkey do: The influence of work groups on the antisocial behavior of employees. Academy of Management Journal, 41, 658-672.

Sackett, P. R. \& DeVore, C. J. (2001). Counterproductive behaviors at work. In N. Anderson, D. Ones, H. Sinangil, \& C. Viswesvaran (Eds.), International handbook of work psychology, 1, London: Sage.

Shore, L. M. \& Barksdale, K. (1998). Examining degree of balance and level of obligation in the employment relationship: A social exchange approach. Journal of Organizational Behavior, 19, 731-744.

Shore, L. M, Tetrick, L. E., Lynch, P. \& Barksdale, K. (2006). Social and Economic Exchange: Construct Development and Validation. Journal of Applied Social Psychology, 36(4), 837-867.

Storms, P. L. \& Spector, P. E. (1987). Relationships of organizational frustration with reported behavioral reactions: The moderating effect of perceived control. Journal of Occupational Psychology, 60, 227234.

Tekleab, A. G., Takeuchi, R. \& Taylor, M. S. (2005). Extending the Chain of Relationships Among organizational Justice, Social Exchange, and Employee Reaction: The Role of Contract Violations. Academy of Management Journal, 48(1), 146-157.

Tsui, A. S., Pearce, J. L., Porter, L. W. \& Tripoli, A. M. (1997). Alternative approaches to the employeeorganization relationship: Does investment in employees pay off? Academy of Management Journal, 40(5), 1089-1121.

West, R. \& Turner, L. (2000). Introducing communication theory. Mountain View, C.A.: Mayfield Publishing Company. 